\title{
RECENSIONI E SEGNALAZIONI
}

\section{Nadia Urbinati (a cura), Thinking Democracy Now. Between Innova- tion and Regression, Milano, Annali della Fondazione Giangia- como Feltrinelli, anno LIII, novembre 2019, pp. 355, € 50,00.}

A dieci anni dalla pubblicazione dell'Annale La democrazia di fronte allo Stato a cura di Alessandro Pizzorno, eventi e tensioni recenti, a livello nazionale e internazionale, hanno riproposto all'attenzione degli studiosi e dell'opinione pubblica il tema delle sfide che le democrazie contemporanee devono affrontare oggi. Questo cinquantatreesimo Annale della Fondazione Feltrinelli propone ora una riflessione articolata delle trasformazioni che le democrazie stanno sperimentando, e lo fa attraverso una ricca analisi critica e con contributi significativi, esplorando paradossi e processi democratici nei diversi paesi. Nadia Urbinati è una politologa di fama internazionale, naturalizzata statunitense, titolare della cattedra di Scienze politiche presso la Columbia University di New York: è inoltre membro del Comitato scientifico della Fondazione Giangiacomo Feltrinelli dove è responsabile scientifico della Linea di Ricerca sull'Innovazione politica. Si occupa del pensiero democratico e liberale contemporaneo e delle teorie della sovranità e della rappresentanza politica; collabora con "La Repubblica" e con "Il Sole 24 Ore". Ha contribuito al dibattito su passato e futuro delle democrazie con due importanti studi: Utopia Europa edito da Castelvecchi e Me the People. How Populism Transforms Democracy per Harvard University Press. In una recente intervista (La voce di New York, 16/05/2020) ha affermato: "Abbiamo internet, abbiamo una democrazia solida che ha 70 anni di regole. Il fascismo non torna, sarebbe assurdo, ma c'è una trasformazione delle democrazie rappresentative perché la rappresentanza non è più gestita dai partiti, ma direttamente dai leader".

Per anni gli intellettuali hanno sostenuto che, con il trionfo della democrazia liberale capitalista, il mondo occidentale aveva raggiunto "la fine della storia". Di recente, tuttavia, sono emersi in molti paesi politiche autoritarie e movimenti nazionalisti e populisti. I concetti di post-democrazia, anti-politica e simili stanno guadagnando peso nel dibattito teorico e politico. Anche le democrazie capitaliste occidentali devono quindi affrontare nuove sfide e diventa sempre più importante indagare non solo l'antagonismo intrinseco tra liberalismo e democrazia, ma anche le radici del populismo. Questo deve essere considerato un antagonista della democrazia? O invece proprio il populismo potrebbe "riformare", 
espandere e persino migliorare la democrazia? Queste sono le domande fondamentali a cui questa raccolta di saggi cerca di rispondere.

Il volume ha come oggetto le trasformazioni che coinvolgono le democrazie contemporanee "from the perspective of their conflicting potentials". Questa analisi non può che essere condotta in chiave comparativa. La natura e le specificità delle diverse democrazie riflettono, infatti, la cultura politica delle società in cui sorgono. Grazie al concorso di studiosi di fama internazionale, l'Annale esamina le più recenti trasformazioni dei processi democratici, analizzandone tendenze regressive e opportunità di innovazione in un orizzonte geopolitico globale. L'analisi si sviluppa intorno a un paradosso significativo: la democrazia gode oggi di un'indiscussa egemonia, al punto che anche chi la mette in discussione lo fa promettendo di rafforzarla o di estenderla, non certo di indebolirla o superarla. Rinata nel Secondo dopoguerra in contrapposizione alle dittature di massa, la democrazia costituzionale è un ordinamento politico che trova giustificazione non nell'ideologia, ma nell'esperienza storica, e per questo è sempre esposta al rischio di implodere verso altri sistemi, autoritari o populisti. A partire da questa premessa, il volume accompagna il lettore attraverso una riflessione che spazia dalle questioni teoriche e istituzionali alle esperienze e sfide politiche più rappresentative dei cinque continenti.

Il volume è diviso, idealmente, in tre parti. Nella prima sono raccolti saggi teorici e metodologici sulle diverse forme di partecipazione, sulle regole procedurali per le elezioni, sul ruolo delle nuove tecnologie nel condizionare la partecipazione. Wolfgang Merkel, in particolare, si chiede se le nuove sfide che le democrazie devono affrontare oggi debbano essere considerate vere e proprie crisi o piuttosto processi di trasformazione. Egli introduce il concetto di democrazia integrata (embedded democracy), ovvero un sistema la cui esistenza dipende da fattori interni ed esterni. Il principio costitutivo centrale (core) è rappresentato dall'esistenza di un regime elettorale: a questo vanno associati la partecipazione, i diritti civili, la cosiddetta responsabilità (accountability) orizzontale, l'effettivo potere di governare. Dal punto di vista esterno un regime democratico è condizionato dallo sviluppo socio-economico, dalle caratteristiche della società e dalla giustizia civile (p. 3): quanto più questi fattori esterni sono sviluppati e stabili tanto più costituiscono un baluardo della democrazia. Quando uno di questi elementi esterni si indebolisce o viene a mancare si potrà quindi parlare di democrazia in crisi. Questo è avvenuto in Polonia (basso ricambio elettorale), in Belgio (difficoltà a creare una coalizione di governo), negli Stati Uniti (sistema di governo incostituzionale di Trump), ma non si può parlare di democrazia difettosa (defective) come invece si è verificato in altri paesi quali Indonesia, India, Equador, Ucraina, Ungheria. Un'analisi dell'evidenza empirica rivela che la qualità delle democrazie in Europa occidentale non è diminuita nè dal punto di vista degli esperti né da quello dei cittadini: è invece diminuita la fiducia nei confronti delle principali istituzioni centrali caratterizzate da un sistema basato sul governo della maggioranza (majoritarian core institutions) come i partiti, i parlamenti e il governo. Si verifica cioè una sorta di paradosso per cui i cittadini non credono più proprio nelle istituzioni da loro elette.

Non esiste una risposta valida in generale alla domanda se la democrazia sia in crisi. Esistono solo specifiche analisi di singoli casi. Nonostante le tendenze alla perdita di fiducia manifestatesi all'interno dell'Unione europea, in alcuni paesi (Germania, Finlandia, Danimarca, Svezia) la democrazia non sembra essere affatto in crisi, e non è in crisi neppure nell'Europa mediterranea. In altri paesi invece, come nelle democrazie dell'Est, in Russia, in Turchia, in Medio Oriente, in America Latina e in Africa, il processo democratico 
non si è ancora consolidato, oppure ha subito un processo di trasformazione illiberale come in Ungheria, in Polonia ed in Brasile (p. 19).

Nella sua bella introduzione e nel saggio The populist transformation of democracy Nadia Urbinati colloca i recenti movimenti populisti all'interno dell'ordine democratico, ben lontano dal fascismo che ne rappresenta un deragliamento. L'autrice è consapevole che anche il fascismo è nato come populismo, ma è ben presto diventato un vero e proprio regime, non avendo avuto il coraggio di accettare il rischio di libere elezioni. Secondo lei, invece, il populismo accetta fino in fondo il rischio di elezioni, al punto da utilizzarle come un vero e proprio plebiscito a favore del leader e della maggioranza degli eletti. La democrazia populista è quindi il nome di una nuova forma di governo rappresentativo basata su una relazione diretta tra il leader e coloro che il leader riconosce come la parte "giusta" del popolo (p. 78). Il nucleo ideologico del populismo è alimentato dalle due entità principali - la nazione e il popolo che hanno rafforzato la sovranità popolare nell'era della democratizzazione. Il populismo consiste quindi in una trasformazione dei princìpi democratici della maggioranza e del popolo finendo con il celebrare un sottogruppo di persone anziché un altro, attraverso un leader che lo incarna e un pubblico che lo legittima. Sotto questo profilo il populismo si scontra con la democrazia costituzionale, anche se i suoi princìi sono incorporati nell'universo democratico dal punto di vista dei significati e del linguaggio. Il populismo considera la propria maggioranza come l'unica legittima, e ritiene che quelle che caratterizzavano le democrazie occidentali siano manovrate dai partiti, dalle élites, dalle minoranze. Questa interpretazione, sostenuta dai populisti per criticare la democrazia rappresentativa, secondo la Urbinati è falsa. La democrazia significa proprio creare quelle maggioranze che hanno il diritto/dovere di governare a seguito delle elezioni. Non v'è dubbio che i nuovi populismi costituiscano una sfida ed un rischio per la democrazia, anche se sono ben diversi dal fascismo così come storicamente l'abbiamo conosciuto. Non si può tuttavia non riconoscere, come ben documenta la Urbinati, che il populismo tende a trasformare i fondamenti stessi della democrazia costituzionale: il concetto di popolo, il significato di maggioranza, la natura delle elezioni e della rappresentanza. Un contributo all'interno della prima parte è dedicato poi a discutere una innovazione nel meccanismo elettorale quale è il recalling, ovvero la possibilità di chiedere la decadenza di un rappresentante eletto: attraverso questo meccanismo i cittadini potrebbero esercitare una sorta di controllo sugli eletti e sulle decisioni di governo. Secondo Jonathan White e Lea Ypi questo strumento ridurrebbe il divario oggi esistente tra cittadini ed élites politiche: i cittadini assumerebbero infatti una maggiore responsabilità decisionale in politica.

Un altro interessante saggio è dedicato ad un problema di grande attualità, quello dei migranti. In particolare Seyla Benhabib analizza le implicazioni per il diritto d'asilo derivanti dal riconoscimento di "rifugiato". Si sottolinea come questa condizione rappresenti una importante sfida, se non un vero e proprio dilemma per le moderne società nelle quali la legislazione oscilla tra il pieno riconoscimento in nome dei diritti umani e la necessità pratica di contenere movimenti in continua crescita. Le successive formulazioni del trattato di Dublino ne sono un esempio. Un esempio estremo di politica nazionalista e protezionistica è poi offerto dal saggio Homo Italicus Orbanicus: l'alleanza a seguito di un "contratto" tra Salvini e il Movimento 5 Stelle viene analizzata come un fenomeno che non ha precedenti e a seguito del quale una alleanza "innaturale" ha consentito di mettere in discussione istituzioni come la Corte Costituzionale e la libertà di stampa. La conclusione di Michele Battini è che quel contratto configura una nuova forma del modello che si era imposto tra le due guerre, fondato sul corporativismo, la tecnocrazia e l'autoritarismo (p. 197). 
Due saggi (di Richard Bellamy e di Turkuler Isiksel) discutono il tema della costruzione dell'Unione europea come antidoto ai nazionalismi precedenti la seconda guerra mondiale e come tentativo di assicurare le condizioni per la nascita, nel lungo periodo, di un regime democratico sovranazionale. Questo progetto, che si basava su concetti di stampo keynesiano, si è progressivamente indebolito a favore di una versione neoliberale. Nello stesso tempo il Trattato di Maastricht, il completamento del mercato unico e la creazione dell'Unione monetaria hanno rappresentato un passo verso l'impossibilità di attuare interventi a sostegno delle economie nazionali, quando siano adottati autonomamente. La discussione verte oggi sulla possibilità, e addirittura la desiderabilità, di realizzare una forma di democrazia sovranazionale con rappresentanti eletti dai cittadini dei diversi paesi. Il fallito tentativo di introdurre una costituzione europea ha rivelato come questo passaggio avrebbe creato un deficit democratico invece che annullarlo: se infatti il trattato fosse stato firmato si sarebbe ridotta la capacità di giungere a decisioni che rispondano a processi democratici interni ai singoli paesi. L'analisi dimostra inoltre come sia possibile che l'Unione economica possa rappresentare una forma di governo democratico a livello di singoli paesi, ma non dei singoli individui. Il pluralismo che caratterizza i diversi Stati dell' Unione nasce sì da divergenze profonde di natura economica, politica e sociale, ma questo non impedisce che si possano individuare i requisiti istituzionali che consentirebbero di dare vita a un sistema democratico transnazionale, ovvero cosmopolita. Il superamento del cosiddetto "deficit democratico" della UE può essere infatti realizzato rafforzando la legittimità democratica dei singoli paesi ed introducendo meccanismi che favoriscano la cooperazione e le reciproche interazioni. Questa è la strada che avrebbe dovuto imboccare il Regno Unito invece di proporre la Brexit. Per Bellamy, abbandonando l'Unione, il governo e i cittadini britannici hanno commesso un errore nei propri stessi confronti e verso gli altri. In un mondo globalizzato essi dovranno infatti sottostare comunque al controllo di altri Stati e delle Organizzazioni Internazionali. L' Unione resta tuttavia una costruzione che non può essere definita democratica: la sua legittimità democratica non può infatti risiedere che nel rafforzamento della democrazia all'interno dei singoli Stati e nell'introduzione di regole e meccanismi che rafforzino la cooperazione tra gli Stati membri. Bellamy individua la soluzione in quello che definisce republican intergovernmentalism (p. 213): formula che dovrebbe consentire agli Stati di cooperare, coesistere e governare insieme senza che vi sia necessariamente un'autorità sovranazionale. Un altro autore, Turkuler Isiksel, sottolinea come l'attuale configurazione dell'Unione, caratterizzata da istituzioni tecnocratiche che non rispettano il principio maggioritario, abbia finito con l'erodere proprio quei princìpi democratici per i quali si era battuto il sostenitore di un percorso dichiaratamente federalista come Altiero Spinelli.

La terza parte del volume è dedicata all'analisi di alcuni sistemi politici extraeuropei come Cina, India, America Latina e Africa sub-sahariana. La caratteristica specifica del modello cinese è individuata nell'impegno a conseguire un robusto processo di sviluppo: al raggiungimento di questo obiettivo sono state subordinate le diverse politiche di apertura, di promozione delle esportazioni e degli investimenti, di controllo della domanda interna. Si tratta di un modello che ha ottenuto un significativo successo, comprimendo tuttavia un'ampia gamma di libertà (di movimento, di diritti di proprietà, di opinione). Tale modello, tuttavia, difficilmente potrebbe essere esportato, e sebbene possa essere considerato quasi un simbolo dei numerosi fallimenti economici, sociali e politici che hanno caratterizzato le democrazie occidentali, non si può non osservare che solo in un sistema democratico il pluralismo è assicurato attraverso la frammentazione ed il bilanciamento dei poteri. 
L'India è certamente una democrazia antichissima, ma molto diversa dai sistemi occidentali. Viene definita da Sudipta Kaviraj come uno Stato "non nazione", in relazione ai suoi caratteri multietnici e multiculturali che impediscono che si possa ricondurre lo Stato ad una identità nazionale. La contrapposizione tra Musulmani e Indu rappresenta inoltre un potenziale esplosivo. Il capitolo di Enrique Peruzzotti analizza, con riferimento all'America Latina, la nascita e lo sviluppo delle diverse forme di populismo. In quel continente fin dagli anni ' 40 un populismo di natura democratica ha rappresentato una presenza costante nata per opporsi sia ai regimi autoritari sia ai sistemi democratico-liberali. Nel momento in cui i regimi populisti si stanno affermando anche in Europa, un'analisi storica dell'esperienza di paesi come l'Argentina, il Brasile e il Venezuela può aiutare a comprendere le sfide che un regime populista pone ai regimi rappresentativi liberali. In America Latina liberalismo e democrazia si sono sviluppati insieme, ma nel periodo successivo alla seconda guerra mondiale vi si è affermata una forma particolare di populismo, il peronismo, come alternativa alle spinte oligarchiche prodottesi. Alla vigilia degli anni 2000 la costituzione da parte di Hugo Chavez della Repubblica "Bolivariana" ha rappresentato un "ibrido" democratico che riprendeva e amplificava alcune caratteristiche del peronismo; il Congresso eletto è stato sostituito da un'Assemblea costituente dotata di potere legislativo: ha preso vita in questo modo un'ondata populista che, partendo dal Venezuela, si è diffusa in Argentina, Equador, Bolivia e Nicaragua. Questi regimi sono nati in seguito al fallimento di regimi rappresentativi liberali: sembra tuttavia che oggi questa fase sia superata e che liberalismo e democrazia possano continuare a coesistere. Un ultimo saggio di questa terza parte è dedicato da Anna Maria Gentili alle democrazie dell'Africa sub-sahariana, la cui situazione sociale e politica è molto complessa, dal momento che l'esistenza di comunità molto diverse tra di loro rende difficile il funzionamento di un sistema democratico.

L'ultimo capitolo di Luca Baldissara, Thinking Democracy Now, costituisce una sorta di sintesi di quanto illustrato nel corso del volume. La democrazia costituzionale e rappresentativa, almeno nei paesi industrializzati occidentali, è solida anche se ha dovuto trasformarsi assumendo forme sempre più vicine al populismo. I problemi sociali, la disuguaglianza e la povertà sono fenomeni sempre più gravi destinati a persistere. Il conflitto è tuttavia inevitabile in sistemi politici non autoritari: si tratta di contenerne la portata, non di eliminarli, e questo controllo può essere esercitato in modo appropriato solo in regimi democratici. In sintesi, e per concludere, non si deve parlare di "crisi" della democrazia, quanto piuttosto di un inevitabile processo di cambiamento che finisce con il rafforzare la democrazia stessa più che indebolirla,

RENATA TARGETTI LENTI

\section{CARola Ricci (ed.), Building an Inclusive Digital Society for Persons with Disabilities. New Challenges and Future Potentials, Pavia, Pavia University Press, 2019, pp. 166, € 16,00.}

The volume Building an Inclusive Digital Society for Persons with Disabilities. New Challenges and Future Potentials, edited by Carola Ricci (University of Pavia, Department of Political and Social Sciences) and published in 2019 by Pavia University Press in an open access format, is one of the outputs of the project Building an Inclusive Digital Society for 
Vulnerable Persons: The Role of Social Media Tools in a Disability Human Rights Perspective - BIDS, funded by the University of Pavia under the call Blue Sky Research 2017. This volume showcases the main findings of the BIDS project and brings together, in an innovative fashion, various strands of research on digital inclusion, web accessibility, digital equality and privacy. It has also the merit to include a range of contributions from different authors at various stages of their career and with different disciplinary backgrounds, opening up a conversation on the opportunities and challenges that digital technologies bring about.

The structure of the volume is clear and well-thought through. Contributions are divided into three thematic sections that streamline the content of the volume and revolve around specific conceptual clusters. The first section addresses the relevant multilevel legal framework from a disability law perspective. It includes contributions from Lisa Waddington and Andrea Broderick (Maastricht University), who focus on accessibility and digital inclusion in the European Union (EU) legal framework, as well as Vittorio Pampanin, who discusses the Italian legal framework. Both Waddington and Broderick highlight the important role of the UN Convention on the Rights of Persons with Disabilities (CRPD) in shaping EU law and ultimately national law, and Waddington inter alia contends that the Regulation of digital goods and services is "occurring at multiple levels and being influenced by different regulatory regimes" (p. 15). Broderick's analysis focuses on the European Accessibility Act (EAA), the recent Directive on accessibility of goods and services approved by the Eu legislature in 2019. This Author suggests that the EAA has begun to pave the way towards digital inclusion and equality for European citizens with disabilities. Pampanin's chapter gives a detailed account of the stratified and inherently multilevel Italian system on accessibility. Pampanin also discusses the so called "Stanca Law" recently amended to implement the Web Accessibility Directive. From the detailed examination proposed it can be inferred that Italian legal framework has been somewhat progressive, but then its implementation is lagging behind. This contrast between good legislation and bad implementation, highlighted by Pampanin, tallies with the finding in other fields and has been noted across Italian disability legislation. The chapters included in second section discuss to varying degrees the major challenges emerging from the widespread use of digital technologies. They focus on the interplay among accessibility, human dignity and privacy concerns. One of the main findings of this section is the need for more research on the balance between contrasting rights. In that connection the volume highlights new ways for research as well as new theoretical approaches that might prove useful to address the challenges brought by technologies. Favalli suggests that, in order to strike a balance between accessibility and privacy, it is important "to look for a different approach in the protection of human rights in the digital environment, thus considering the changing capabilities of individual users" (p. 65). In that vein, this Author evokes the capability approach that has been developed by Amartya Sen (Development as Freedom, Oxford University Press, 1999) and advanced by philosopher Martha Nussbaum (Creating Capabilities: The Human Development Approach, Harvard University Press, 2011). In a similar vein, Falconi in her chapter on hate speech suggests that there is a strong need "to develop existing principles" to tackle in a comprehensive manner disability hate speech in order to achieve "better outcomes for all disabled people and contributing to a community where individual dignity and equality is granted to everyone, without unduly curtailing freedom of expression" (p. 79). Finally, the third section is the most varied and interdisciplinary as it analyses some best practices that if scaled up will create a digitally inclusive society. This final section features a valuable contribution by Carola Ricci, which presents the multi-stake- 
holders' approach that actually informs the book and the overall project that led to the completion of the volume. In line with this approach, the book moves away from a purely legaldoctrinal analysis to incorporate interdisciplinary pieces based on lived experiences in different contexts.

There are four overarching aspects of the volume that can be considered particularly innovative and noteworthy. First, the book engages with both web accessibility and data privacy as necessary preconditions to enhance digital inclusion. Too often privacy has been used as a shield in order to avoid adopting accessibility measures (as highlighted well by Favalli in her contribution). By contrast, all chapters, albeit to a different extent, make very clear that accessibility should be prioritized at the same level as privacy and security. In this respect, the book importantly calls for a more comprehensive approach not only for lawyers, but also for those developing and commercializing digital technologies. Secondly, the book has also the merit of explicitly adopting a disability human rights perspective, and sheds a different light on the wide discourse on the impact of new technologies. Thirdly, the book engages with a multilevel approach to the legal analysis. It provides the reader with a better understanding of the role of international and supranational law in shaping an effective national legal framework that enable people with disabilities to access digital technologies on an equal basis with others. In that connection, an important strength of the book is that it recognizes (aligning with the most recent literature) that the CRPD has become the global legal and conceptual benchmark for disability policies. Finally, the adoption of the abovementioned multistakeholders' approach is also a very interesting feature of the book, highlighting the role of civil society and disabled people organizations in shaping laws and policies and in supporting and monitoring their implementation. Ricci in particular, in line with the principle of participation enshrined in the CRPD, suggests that "persons with disabilities along with civil society must be actively involved in a 'multi-stakeholder alliance' to participate in the policy-making process, in order to foster the adoption of appropriate legislative reforms, to spread existing best practices and to raise awareness on such emerging topics among the whole society" (p. XVIII). The volume leaves open some questions on how this multi-stakeholders' approach should be realized in practice and on the actual challenges of participatory processes. However, it succeeds in signaling the need for further investigation and stimulates an open dialogue among academia and civil society.

Alongside the combination of these four aspects, an overall strength of this book is that, notwithstanding the recognition that technology can be a Ianus Bifrons or a doubleedged sword, policy makers will need to engage with the "mainstreaming" of "concepts such as digital inclusion, e-accessibility and digital equality in the current legal and policy framework is both crucial and urgent to develop a fully inclusive society".

DELIA FerRI

\section{RAINER ZiTELMANN, La forza del capitalismo. Un viaggio nella storia re- cente dei cinque continenti, Torino, IBL Libri, 2020, pp. 348, $€ 20,00$.}

Il volume qui in considerazione è una traduzione dall' originale tedesco Kapitalismus is nicht das Problem, sondern die Lösung. In esso, Rainer Zitelmann, dottore di ricerca in storia e sociologia, affronta il tema del capitalismo e dell'anticapitalismo a partire dall'os- 
servazione storico-empirica. In altre parole, si prefigge di esaminare cosa ha funzionato e cosa non ha funzionato nell'adozione di misure favorevoli all'economia di mercato o, per contro, di pianificazione economica in un medesimo paese (Cina, Regno Unito, USA, Svezia), in paesi diversi ma caratterizzati dalla medesima storia e cultura (Cile e Venezuela, Repubblica Federale Tedesca e Repubblica Democratica Tedesca, Corea del Sud e Corea del Nord) e nel continente africano.

Va detto subito che si tratta di un testo militante, come traspare dal titolo stesso del libro. Infatti, attraverso dati, statistiche e analisi storiche, Zitelmann sostiene la tesi che "il capitalismo è la causa principale dell'aumento globale del tenore di vita su una scala senza precedenti nella storia dell'umanità prima dell'avvento dell'economia di mercato"' (p. 24).

Seguendo un'ispirazione misesiana, l'Autore parte dall'idea che un'economia moderna può essere organizzata secondo due distinti principi, sebbene nessuno dei due sistemi sia mai esistito in forma pura: da un lato, lo stato detiene la proprietà di ogni bene (sistema socialista; in esso rientrano, per dirla con Ludwig von Mises, tanto il modello burocratico "di Lenin o russo o marxista", quanto quello "di Hindenburg o tedesco o di Zwangswirtschaft" in cui la proprietà privata è solo nominalmente esistente); dall'altro lato, vige la proprietà privata dei mezzi di produzione (sistema capitalista o ad economia di mercato). Ciò che desta maggiore preoccupazione, secondo Zitelmann, non è tuttavia la nazionalizzazione delle imprese, come poteva capitare in passato, bensì la graduale limitazione del capitalismo attraverso l'aumento dei poteri di pianificazione e redistribuzione da parte dell'autorità statale, con particolare enfasi posta sull'azione pianificatrice che le banche centrali stanno operando: in altre parole quello che Mises definiva "interventismo" (e che, secondo Hayek, avrebbe condotto verso "La via della schiavitù").

Scriveva Mises in "Socialismo", che la crisi del capitalismo non era da considerarsi veramente tale, bensì come una crisi dell'interventismo che richiede sempre maggiori interventi per correggere i fallimenti degli interventi precedenti: "se il governo, posto davanti a questo fallimento del suo primo intervento, non è pronto ad annullare questa sua interferenza nel mercato e a ritornare a una economia libera, esso deve aggiungere a questa sua prima misura sempre di nuovo e sempre di più regolamentazioni e restrizioni. Andando avanti passo dopo passo in questo modo alla fine esso perviene a un punto in cui è scomparsa qualsiasi libertà degli individui. È così che emerge un socialismo del tipo tedesco, la Zwangswirtschaft" che formalmente non sopprime la proprietà privata, ma che sostanzialmente la rende sempre meno concretamente effettiva. L'Autore, in buona misura, ricalca la tesi misesiana.

Il caso forse più emblematico che Zitelmann riporta nel volume è il paragone tra Germania Est e Germania Ovest. Non a caso, il capitolo ad esso dedicato - il terzo - comincia così: "senza volerlo, la Germania è diventata per un certo periodo il luogo in cui si svolse un esperimento su larga scala per verificare se gli esseri umani hanno maggiori probabilità di prosperare in un'economia controllata dallo stato o nel libero mercato" (p. 89). Com'è noto, dopo la fine della Seconda guerra mondiale, la Germania venne suddivisa in quattro zone di occupazione. Poco dopo la fondazione della Repubblica Federale Tedesca (Bundesrepublik Deutschland, BRD), quella controllata dai sovietici divenne nel 1949 la Repubblica Democratica Tedesca (Deutsche Demokratische Republik, DDR). In essa vigeva una forma di economia di stampo socialista: espropriazioni e nazionalizzazioni erano la prassi. Tutte le imprese statali erano tenute a presentare innumerevoli rapporti dettagliati all'autorità di pianificazione economica, giacché, come spiegato da un'economista comunista citato dall'Autore, Fritz Selbmann, "in un'economia pianificata ogni singolo dettaglio della produzione è deciso a 
tavolino; ogni processo economico, dall'approvvigionamento delle materie prime al trasporto, dalla lavorazione alla vendita, è pianificato in anticipo" (p. 92). Dunque, se in un'economia libera, il mercato ha la funzione di far incontrare domanda e offerta, in modo tale che si formino spontaneamente i prezzi, allocando così in maniera razionale le risorse scarse, in un'economia di piano, per contro, i prezzi e la produzione sono stabiliti aprioristicamente secondo uno schema ingegneristico. Al netto dell'ingente numero di persone che, prima della costruzione del Muro, fuggirono verso l'Ovest, il fallimento dell'economia di piano di marca sovietica era evidente: nel 1960, ricorda l'Autore, l'offerta di beni era drasticamente scarsa e, senza l'aiuto dell'URSS, il sistema sarebbe collassato.

Nel momento in cui viene soppresso il meccanismo di mercato, la scarsità di beni (e la pessima qualità di quelli a disposizione) segue in modo quasi automatico. Allo stesso modo, il divario tecnologico tra DDR e il mondo occidentale era siderale: pur avendo investito tra il 1986 e il 1989 quattordici miliardi in marchi orientali per un programma di microelettronica, Honecker dovette constatare che il costo di produzione per un chip di memoria da 256 kilobit era in patria di 534 marchi orientali, mentre la stessa componente costava soli quattro o cinque marchi sul mercato globale (p. 105).

In modo antitetico, pur dopo un'iniziale fase poco favorevole al mercato, a seguito dell'elezione di Konrad Adenauer a cancelliere nel 1949 la Germania Ovest conobbe una svolta orientata all'economia di mercato. Il principale artefice di questo radicale cambiamento fu Ludwig Erhard, ministro dell'economia tra il 1949 e il 1963 e successore di Adenauer alla Cancelleria tra il 1963 e il 1966. Secondo Erhard, l'economia di mercato costituiva il motore del benessere sociale in sé e le misure da egli adottate in tal senso furono la precondizione per il cosiddetto Wirtschaftswunder, il miracolo economico tedesco. Come ricorda Zitelmann, infatti, tra il 1948 e il 1960 il PIL pro capite aumentò mediamente di più del 9\% annuo e continuò a crescere del 3,5\% tra il 1961 e il 1973 (p. 113). L'ideale erhardiano è ben riassunto in un passo contenuto in suo volume pubblicato nel 1957, Benessere per tutti: "l'ideale che ho in mente si basa sulla forza dell'individuo che afferma: voglio mettermi alla prova con i mezzi che possiedo, voglio assumermi i rischi della vita, voglio essere responsabile del mio destino. Sta a te, stato, assicurarti che io sia in grado di farlo". L'appello dell'individuo allo stato non deve essere "vieni in mio aiuto, proteggimi e aiutami", ma il contrario: "stai fuori dai miei affari, ma lasciami la libertà e i miei guadagni, in modo che io possa plasmare la mia esistenza, il mio destino e quello della mia famiglia" (p. 115). Una visione, come nota l'Autore, che non si discostò molto da quella fatta propria da Margaret Thatcher nel Regno Unito e da Ronald Reagan negli Stati Uniti (p. 167).

Insomma, pur se il capitalismo ha creato le condizioni per un'esistenza complessivamente più prospera, come è possibile che esso continui a non godere di buona reputazione? Considerate le evidenze storico-empiriche, le quali dimostrano una superiorità di siffatto modello rispetto a modelli di pianificazione ed esacerbato interventismo, come si spiega che l'anticapitalismo si dimostri essere ancora così abbacinante, in modo particolare tra gli intellettuali? Le spiegazioni possono essere molteplici. Joseph Schumpeter, ad esempio, in "Capitalismo, socialismo e democrazia" sostenne che l'aumento della percentuale di coloro che hanno un'istruzione superiore crea un numero di laureati che sono in eccedenza rispetto alla domanda di impiegati ma che sono, al contempo, anche troppo qualificati per i lavori manuali. Lenin, Kautsky e Hayek, ricorda curiosamente Zitelmann (p. 262), si trovano d'accordo sul fatto che il socialismo non è mai stato un movimento spontaneo, bensì è frutto di un'elaborazione cosciente degli intellettuali. Al contrario, il capitalismo è il risultato spontaneamente emerso dal- 
l'interazione di individui: impiegando la terminologia hayekiana, il primo è una taxis e il secondo un cosmos. Inoltre, può essere anche affermato che gli intellettuali, tendenzialmente dotati di un alto livello di istruzione, si trovano mossi da una certa invidia livorosa nei confronti degli imprenditori che hanno successo: i primi sono caratterizzati da alta eticità, i secondi sono dediti al mero guadagno e mirano esclusivamente ad arricchirsi.

Ma se tutti queste spiegazioni hanno una loro certa fondatezza, Zitelmann si muove in una direzione parzialmente differente: "l'ostilità di molti intellettuali verso il capitalismo [è] guidata dall'ingiustificata supremazia che essi assegnano alla propria definizione di conoscenza o di acquisizione della conoscenza, la quale li rende ciechi di fronte all'esistenza di altri tipi di conoscenza o di altri metodi di acquisizione del sapere che sono molto più rilevanti per il successo economico" (p. 271-272). Si può dire, infatti, che esistano almeno due tipi di conoscenza: la prima origina da un "apprendimento esplicito", frutto dello studio sui libri; la seconda è, al contrario, acquisita tramite un "apprendimento implicito", ovvero, ad esempio, da un imprenditore che, sul campo, capisce cosa, come e quanto produrre di una merce o di un bene (p. 272). Michael Oakeshott, in un importante saggio pubblicato nel 1947, "Rationalism in Politics", argomentava che la conoscenza coinvolta in qualunque attività umana è di due tipi: la prima è di tipo tecnico e può essere esplicitamente formulata e codificata; la seconda, invece, è di tipo pratico ed esiste solo nell'uso senza potere essere formulata mediante regole e precetti. È precisamente questo secondo tipo di conoscenza che è impiegata nel mercato ed è proprio questa che rimane ignota al pianificatore centralizzato (emblema, quest'ultimo, della hybris tipica del "razionalismo in politica" di cui parlò il filosofo politico britannico).

Come scrisse Hayek in un saggio del 1945 "si può ammettere che, per quanto riguarda la conoscenza scientifica, un corpo di esperti opportunamente scelto si trovi forse nella posizione migliore per controllare la conoscenza disponibile $[\ldots]$ ma una breve riflessione può mostrare che esiste senza dubbio una conoscenza molto importante, ma non organizzata, che non può essere considerata scientifica, perché non è conoscenza di leggi generali: la conoscenza delle circostanze particolari di tempo e di luogo. Rispetto a questo tipo di conoscenza, ogni individuo si trova praticamente in vantaggio su tutti gli altri, per la ragione che egli possiede informazioni uniche" ("L'uso della conoscenza nella società" in "Competizione e conoscenza", Soveria Mannelli, Rubbettino, 2017, p. 60). Solamente attraverso il meccanismo di esplorazione dell'ignoto e correzione degli errori, tipico dell'economia di mercato, si possono creare le condizioni del benessere materiale: "Il compito singolare dell'economia è di mostrare agli uomini quanto poco essi realmente sanno su ciò che credono di poter pianificare" (F.A. von Hayek, "La presunzione fatale. Gli errori del socialismo", Milano, Rusconi, 1997, p. 134). La guerra al capitalismo promossa da intellettuali e socialisti di ogni tipo, dimostra Zitelmann, è il miglior modo per creare un mondo nuovamente immiserito.

CARlo Marsonet

\section{Angelo Panebianco, Sergio Belardinelli, All'alba di un nuovo mondo, Bologna, il Mulino, 2019, pp. 132, € 12,00.}

Angelo Panebianco e Sergio Belardinelli, rispettivamente ordinario di scienza politica presso l’Università di Bologna e ordinario di sociologia dei processi culturali e comunica- 
tivi presso il campus di Forlì del medesimo Ateneo, hanno insieme dato alle stampe questo volume breve, ma assai denso. Essendo afferenti a discipline diverse, il taglio dei loro contributi al tema dell'Europa, dell'Occidente e della crisi del mondo moderno assume caratteri differenti sì, ma pienamente complementari. Se il primo si focalizza sulle dinamiche politiche e geopolitiche, mentre il secondo su quelle culturali, entrambi prediligono un approccio che definiscono "realismo liberale".

Essi, infatti, condividono l'idea che "la civiltà liberale, con i suoi principi, le sue istituzioni, le sue regole, sia il più importante "dono" dell'Europa moderna. È nata in Europa, e poteva nascere solo in Europa, proprio in ragione delle sue origini cristiane" (p. 10). Se è ben vero che l'ideale di civiltà liberale rimane una sorta di idealtipo weberiano, è altrettanto indiscutibile che, pur con tutte le loro imperfezioni e i loro limiti, le società europee ed occidentali costituiscono gli esempi più prossimi a quella che Karl Popper chiamava "società aperta": un tipo di società che riconosce agli individui un ampio margine di libertà, dignità e diritti sconosciuti nelle altre parti del mondo. Al contempo, il realismo di cui si servono gli Autori consente loro di "osservare la realtà per come essa è, e non per come ci piacerebbe che fosse" evitando in tal modo "fughe nell'irresponsabilità" (p. 11).

Secondo Panebianco, il principale pericolo per l'Europa e il mondo occidentale nel suo complesso è impersonificato dalla Cina. Le mire espansionistiche di Xi Jinping, infatti, si servono della dimensione economica, ma con l'obiettivo di "creare un'immensa ragnatela capace di avvolgere la gran parte del continente euroasiatico, una ragnatela che faccia capo a un grande ragno", ovvero un redivivo "Impero Celeste" (p. 58). La Russia, per rimanendo un attore diverso rispetto al mondo occidentale e dotato di un potere militare non trascurabile - è la seconda potenza militare del mondo - nondimeno risente della propria fragilità in ambito economico. Certamente, da un punto di vista geografico, si trova in una posizione più felice rispetto alla Cina, ma a suo svantaggio gioca pure il fattore demografico in declino. A questo "Oriente" esterno, tuttavia, Panebianco nota come un "Oriente" interno all'Europa e all'Occidente costituisca un'insidia da non sottovalutare: si tratta, com'è intuibile, dell'Islam. Oltre al fatto che, a vantaggio del mondo islamico, intraeuropeo ed extraeuropeo, il fattore natalità giochi un ruolo dirimente, è una certa stanchezza degli europei che li rende poco capaci di fronteggiare le sfide culturali che l'islam propone. Se è ben vero, come ad esempio Luciano Pellicani ha notato a più riprese, che la storia della società occidentale si configura come la lotta intestina e permanente tra società aperta $\mathrm{e}$ società chiusa, tra i sostenitori dell'una e gli adepti dell'altra - scontro paradigmaticamente riscontrabile nel pensiero dicotomico di Benjamin Constant e Jean-Jacques Rousseau - è parimenti vero che l'Occidente si trova a fronteggiare in modo perenne anche i nemici esterni. E se l'Oriente sembra oggi più vicino, è anche perché, scrive Panebianco, "una parte degli europei è acquiescente nei confronti di usi e costumi [...] che sono in conflitto con regole e principi della società aperta o libera" (p. 65).

Da un punto di vista più squisitamente geopolitico, il politologo sostiene che "se viene meno il primato occidentale non c'è ordine internazionale possibile" (p. 66). Pur con tutte le sue imperfezioni, l'ordine liberale, caratterizzato dal primato statunitense legato all'alleanza stretta con l'Europa, "offre più di quanto prende, distribuisce beni pubblici (condizioni favorevoli allo sviluppo economico, sostegno alla democrazia e, quindi ai governi per consenso, preservazione della pace) il cui afflusso è nell'interesse di tutti non interrompere" (p. 69). Insomma, asserisce il politologo, esso si dimostra essere migliore di qualsiasi alternativa, giacché in grado di offrire maggiori garanzie di altri tipi di ordine, 
mediante regole formali e informali tendenzialmente chiare e trasparenti, così come un minimo di protezione agli individui dall'arbitrio e dalla violenza. Se la società aperta è un bene da preservare, in sostanza, l'impegno degli occidentali è quello di tutelare l'ordine internazionale liberale.

Sono però gli europei in grado di fronteggiare una simile sfida a livello culturale? Il contributo di Belardinelli si situa precisamente in questo solco, con particolare attenzione posta alla dimensione cristiana e cattolica dell'Europa. "La crisi dell'Europa come realtà politica - scrive il sociologo - è soprattutto una crisi di fiducia e d'identità' (p. 121). L'Europa e l'Occidente, più in generale, sono quei luoghi in cui la tradizione ebraica, la filosofia greca, la tradizione romana, la fede cristiana e la modernità liberale s'impastano dando vita a un singolare e fecondo unicum. Come scrisse Leo Strauss, ricorda Belardinelli, "il segreto della vitalità dell'Occidente" sta proprio nell'antagonismo tra Atene e Gerusalemme, tra il luogo della filosofia e della ragione e quello della rivelazione e della fede (p. 93). Teoricamente inconciliabili, nella realtà concreta essi sono gli assi dell'anima europea. Epperò, è proprio "nella stanchezza sia della politica sia della religione il vero problema dell'Europa di oggi" (p. 120).

L'Europa e l'Occidente hanno smarrito quel senso di unicità, quello spirito che li rendeva così forti e robusti. L'apertura incondizionata all'altro, frutto di un certo relativismo e di uno smarrimento dovuto alla perdita di senso religioso, sta lì a dimostrare quanto la crisi d'identità sia profonda e lacerante. Già Joseph Ratzinger, d'altro canto, lo aveva ben notato: “C'è un odio di sé dell'Occidente che è strano e che si può considerare soltanto come qualcosa di patologico: l'Occidente tenta sì in maniera lodevole di aprirsi pieno di comprensione a valori esterni, ma non ama più stesso; della sua propria storia vede ormai soltanto ciò che è deprecabile e distruttivo, mentre non è più in grado di percepire ciò che è grande e puro. L'Europa per sopravvivere ha bisogno di una nuova - certamente umile e critica - accettazione di sè stessa, se vuole sopravvivere". Salvador De Madariaga una volta scrisse che "cristiana nella sua volontà, l'Europa è socratica nella sua mente". La mente, purtroppo, sembra offuscata, mentre la volontà pare ormai imbolsita: e se, come Husserl ci ha lasciato detto, "il maggior pericolo dell'Europa è la stanchezza", faremmo bene a riscoprire quell'identità europea unica e irripetibile, sebbene aperta all'altro, se non vogliamo che, dall'esterno, veniamo sopraffatti a causa delle nostre stesse debolezze.

C. M.

\section{Giuseppe Celi, Andrea Ginzburg, Dario Guarascio, Annamaria Si- MONAZZI, Una Unione divisiva. Una prospettiva centro-periferia della crisi europea, Bologna, il Mulino, 2020, pp. 304, € 26,00.}

La storia dell'integrazione europea resta ancora oggi, a sessantatré anni dalla fondazione della Comunità Economica Europea, uno dei temi fondamentali per comprendere l'Unione e i suoi sviluppi politici. Molti dei conflitti, delle tensioni, dei problemi strutturali e delle inefficienze che si riconducono all'Unione Europea, così come anche molti dei successi e delle fortune, sono realmente comprensibili soltanto con una conoscenza della storia delle istituzioni europee e della progressiva integrazione degli Stati Membri. Si tratta di un processo complesso che evidentemente tocca ambiti molto differenti tra loro (econo- 
mico, politico, giuridico, sociale e culturale) e sul quale, purtroppo, nel dibattito pubblico si discute pochissimo e, quando lo si fa, si raccontano, non di rado, versioni che spesso non corrispondono alla realtà dei fatti. Il volume in oggetto certamente contribuisce non solo a comprendere alcuni processi politici, economici ed istituzionali della storia dell'Unione Europea ma anche a inquadrare i fenomeni politici in corso che dividono le opinioni pubbliche degli Stati Membri dell'UE.

La tesi dalla quale partono gli autori è la seguente: il progetto europeo, sebbene sia stato concepito e si sia sviluppato con l'obiettivo di promuovere la convergenza e l'armonizzazione tra gli Stati membri, ovvero di ridurre le asimmetrie interne all'uE, ha acuito tali divergenze e disuguaglianze economico-sociali. In questo senso, la globalizzazione e l'europeizzazione non possono essere considerati fenomeni separati perché pur trattandosi di due livelli di deregolamentazione, la globalizzazione (che ha avuto origine negli Stati Uniti) è stata trasferita in Europa grazie e tramite l'unione monetaria. Secondo gli autori, infatti, 'l'europeizzazione può essere interpretata come l'applicazione a livello dell'Unione Europea, di una politica di deregolamentazione dei mercati dei beni e dei capitali simile al modello anglosassone. Deregolamentazione dei mercati del lavoro e finanziarizzazione hanno dunque inciso sui tempi, sulla forma e sulla direzione del processo di integrazione europea" (pag. 9). Questa tesi, molto netta e chiara, è argomentata con una solida ricostruzione storica ed economico-politica dell'integrazione europea.

Gli autori individuano linee di frattura tra centro e periferia, tra Nord e Sud Europa e di queste con l'Europa dell'Est. Per descrivere queste linee di conflitto gli autori individuano un percorso storico ed economico in cui si ripercorrono le tappe della radicalizzazione delle fratture in seno all'unione monetaria a partire dal rapporto Werner del 1970 per arrivare alla crisi economico-finanziaria del 2009.

Gran parte del libro è dedicata alle diseguaglianze tra l'Europa meridionale e il centro-nord Europa. Dall'analisi emergono chiaramente le asimmetrie interne all'Unione. Paesi come la Repubblica Federale tedesca sono riusciti a riformare mentre altri, a causa di una liberalizzazione eccessiva e prematura, sono rimasti indietro. Gli autori argomentano che il limite dei Paesi dell'Europa del Sud non è dato, come sostiene sovente la Commissione Europea, dalla scarsa flessibilità dei mercati del lavoro, quanto piuttosto "da una limitata capacità di operare in un regime in cui prevale l'innovazione, di prodotto, di processo e organizzativa" (pag. 14). In questo senso vengono sottolineati con molta evidenza come sia indispensabile distinguere tra i paesi di prima industrializzazione, ovvero il centro dell'Europa, i paesi di seconda industrializzazione (Italia) e, infine, i paesi di terza e ultima generazione (Spagna, Portogallo, Grecia). Si evidenzia, inoltre, come "le differenze nella struttura produttiva tra centro e periferia, inizialmente molto ampie, si sono ridotte all'inizio degli anni Settanta [...] per poi riaprirsi negli anni successivi, soprattutto dopo la crisi del 2008." (pp. 85-86). In altri termini le politiche liberiste e neoliberiste che si sono gradualmente imposte a partire dalla fine degli anni Settanta non sono state accompagnate da una base produttiva in grado di sostenere gli effetti perversi della concorrenza nel mercato globale. La finanziarizzazione dell'economia dei paesi periferici - con tutte le conseguenze economico-sociali che ha comportato - è stata possibile ed è stata accelerata dal processo di integrazione europea (pp. 101-112).

Un tema ricorrente nel lavoro in oggetto è il ruolo della Germania nel processo di integrazione europea e nell'attuale impianto economico dell'Unione. Gli autori ricordano giustamente che alla base del divario tra centro e periferia vi è la riorganizzazione della 
produzione e degli scambi in cui un fattore chiave è stato l'espandersi a Est della manifattura europea e della strategia economica e politica della Repubblica Federale tedesca dopo la caduta del Muro di Berlino. Scrivono gli autori che, a partire della metà degli anni Novanta, l'organizzazione della produzione del network del commercio estero tedesco ha subito cambiamenti sostanziali dal punto di vista sia della loro composizione sia della loro articolazione geografica (p. 152). A questo si aggiunga che in un contesto di disgregazione generale la Germania, al centro dell'Europa, è stato l'unico Paese ad unirsi ed acquisire una centralità geografica, economica e politica persa da tempo.

L'intento di Una Unione divisiva. Una prospettiva centro-periferia della crisi europea è di evidenziare le differenze strutturali interne all'Unione. Queste sarebbero dovute essere appianate dal progetto europeo ma così non è stato. Del resto, la diseguaglianza - non tanto tra Stati Membri quanto tra aree geografiche dell'Europa - è evidente. Gli autori individuano in quello che definiscono dogmatismo tedesco e nel suo modello neomercantilista il problema di tali diseguaglianze. Il paradosso è che proprio quel modello, fortemente criticato per come è stato applicato fuori dai confini tedeschi, resta ancora oggi il modello privilegiato per uscire dalle crisi, in quanto considerato più solido, più sicuro e più affidabile: "La politica economica tedesca ha fornito un modello da seguire per uscire dall'impasse della crisi petrolifera, della stagflazione e della prima grande ristrutturazione industriale del dopoguerra" (p. 278).

Il processo di integrazione europea ha avuto un'accelerazione dopo la caduta del Muro di Berlino (1989) e alcuni Paesi come l'Italia, la Grecia e la Spagna avrebbero dovuto aspettare prima di fare il salto nella moneta unica. A questo si aggiunga che l'esiguità e l'inconsistenza del bilancio europeo, privo di imposte europee, non hanno permesso agli Stati aderenti all'Eurozona di beneficiare degli stimoli fiscali (p. 214).

In conclusione, il messaggio di questo libro, alla luce delle crisi degli ultimi anni, consiste probabilmente nel "valutare meglio i limiti delle soluzioni proposte per far uscire l'economia dell'UME dallo stallo attuale. Misure di austerità, riforme strutturali e svalutazione interna (flessibilità salariale) nei paesi debitori (Sud Europa), o espansione della domanda interna nei paesi con spazio fiscale (Germania, Paesi Bassi) non vanno alla radice dei problemi di sviluppo e sostenibilità del debito dei Paesi del Sud Europa, che hanno visto le loro strutture produttive devastate dalla lunga crisi e dalle politiche di austerità" (p. 275). In altri termini, è ormai evidente che esistono almeno due Europe, una centrale ed una meridionale e periferica. Queste due macro aree europee hanno esigenze e aspettative differenti. Il progressivo allargamento dell'Unione Europea non ha fatto altro che acuire tali differenze che inizialmente si è fatto finta di non vedere ma che sono esplose a partire dalla crisi del 2008-2009. Le divisioni interne sono emerse chiaramente durante le dure trattative sul piano di ricostruzione (Next Generation EU) in cui i leader politici non sono riusciti a individuare un reale interesse comune europeo quanto piuttosto una sommatoria di interessi nazionali che dovevano essere soddisfatti. Una Unione divisiva descrive molto bene la trasformazione del progetto europeo dalle mutazioni ideali e dall'elaborazione politico-culturale delle origini alla realizzazione politico-istituzionale del XXI secolo in cui l'Unione Europea è diventata uno spazio economico in cui si manifestano le battaglie politiche dei governi nazionali.

Seppur scritto e pubblicato prima della crisi originata dall'emergenza sanitaria del COVID-19 il libro non ha perso attualità e rilevanza. L'auspicio degli autori è che le istituzioni europee rovescino le misure deflazionistiche, superino il patto di stabilità e che 
trovino "una soluzione condivisa al problema del debito" (p. 275). Tale proposta sembra essere stata in parte accolta dalle risposte che le istituzioni europee hanno individuato per rispondere alla crisi pandemica e ai suoi effetti economico-sociali. In particolare la sospensione del patto di stabilità è una svolta storica per l'Unione Europea perché non si sa quando e come verrà riattivato. Inoltre anche il piano di ripresa Next Generation $E U$ è indirizzato a sostenere e aiutare le aree geografiche periferiche. Resta naturalmente il problema di fondo per cui proprio la struttura del Next Generation EU rappresenta una faticosa sintesi tra gli Stati Membri sempre più divisi da quelle linee di frattura descritte nel libro.

UbALDo VilLANi LUBELLI 